\title{
30. LATE QUATERNARY VARIATIONS IN PLANKTONIC FORAMINIFER FAUNAS AND PTEROPOD PRESERVATION IN THE EQUATORIAL INDIAN OCEAN ${ }^{1}$
}

\author{
James L. Cullen ${ }^{2}$ and André W. Droxler ${ }^{3}$
}

\begin{abstract}
At Site 716, drilled during Ocean Drilling Program Leg 115, a long continuous carbonate-rich sequence was recovered from a shallow $(533 \mathrm{~m}$ ) basin within the Maldives region of the Chagos-Laccadive Ridge. The oxygen isotope stratigraphy, along with four internally consistent biostratigraphic datums, indicates a late Quaternary record with a sedimentation rate of $3 \mathrm{~cm} / 1000 \mathrm{yr}$, a rate rarely found in the equatorial Indian Ocean. Thus, the upper $18.4 \mathrm{~m}$ of Hole $716 \mathrm{~B}$ provides us with an excellent opportunity to conduct high-resolution studies of changes in foraminifer faunas and aragonite preservation within a time-stratigraphic framework established by oxygen isotope stratigraphy.

Analyses of two indicators of aragonite preservation (\% whole pteropods, $\%$ pteropods) reveal significant variability over the past $600,000 \mathrm{yr}$. A long interval of poor aragonite preservation occurs during isotope stages $9-13(\sim 300-500$ k.y.). Significant smaller amplitude and higher frequency $\left(1 / \mathrm{f}\right.$ on the order of $\left.10^{4} \mathrm{yr}\right)$ aragonite preservation fluctuations occur throughout the last $600,000 \mathrm{yr}$.

Analyses of the indicators of calcite preservation (\% whole foraminifers and $\%$ whole Globorotalia menardii complex) reveal low variability and high levels of calcite preservation throughout the section. Excellent preservation enables us to evaluate downcore changes in the relative abundance of foraminifer species in terms of changes in environmental conditions of equatorial Indian Ocean surface waters and without regard to dissolution.

The seven most abundant foraminifer species exhibit considerable systematic downcore variation, with ranges of variability approaching $15 \%$. All seven species exhibit statistically independent high-frequency $\left(1 / \mathrm{f}\right.$ on the order of $10^{4}$ yr) variability, with the two most abundant species (Globorotalia ruber and Globorotalia dutertrei) exhibiting a series of low-frequency $\left(\mathrm{l} / \mathrm{f}\right.$ on the order of $\left.10^{5} \mathrm{yr}\right)$ maxima and minima. A set of similar, well-preserved, northern Indian Ocean analogs was found for all Hole 716B samples. The Modern Analog Technique was used to calculate sea-surface temperature (SST) changes at Site 716 over the past $600,000 \mathrm{yr}$ for the warm and cold seasons. Warm SSTs show little variation and are similar to modern values (near $28^{\circ} \mathrm{C}$ ). Cold SSTs are consistently cooler than the modern values that dip below $26^{\circ} \mathrm{C}$ during glacial isotope stages 6 and 8 . The absence of large SST changes and the presence of considerable species variation indicate that foraminifer faunas are responding to non-SST-related environmental changes in surface waters, such as changes in salinity and/or nutrient levels.
\end{abstract}

\section{INTRODUCTION}

The production and composition of biogenic carbonate in the equatorial Indian Ocean are related to environmental conditions of surface waters that are under the direct influence of the unique monsoon climatic and oceanographic setting of the northern Indian Ocean. In addition, because sites of accumulation on the sea bottom cover a wide depth range as a result of the region's complex physiography, the biogenic carbonate reaching the ocean floor is further modified to varying degrees by the depth-related process of differential dissolution.

The physiographic features of the equatorial Indian Ocean include a series of deep basins separated by three north-trending linear topographic highs: the Ninetyeast, Chagos-Laccadive, and Carlsberg ridges. The deep basins are covered with low-carbonate siliceous clay and ooze, and the ridges and other topographic highs are blanketed with high-carbonate oozes.

Equatorial Indian Ocean pelagic sequences from the topographic highs can provide us with continuous Neogene carbonate-rich sequences for high-resolution paleoceanographic studies. However, most carbonate-rich sequences from the region, even those well above the lysocline, exhibit late Neogene rates of sedimentation that rarely exceed $\sim 1 \mathrm{~cm} / 1000 \mathrm{yr}(10 \mathrm{~m} / \mathrm{m} . \mathrm{y}$.).

\footnotetext{
${ }^{1}$ Duncan, R. A., Backman, J., Peterson, L. C., et al., 1990. Proc. ODP, Sci. Results, 115: College Station, TX (Ocean Drilling Program).

2 Department of Geological Sciences, Salem State College, Salem, MA 01970, U.S.A.

${ }^{3}$ Department of Geology and Geophysics, Rice University, Houston, TX 77251,
} U.S.A.
At Site 716 during Ocean Drilling Program (ODP) Leg 115, we recovered a long, continuous late Neogene sediment section from a broad shallow basin in the Maldives region of the Chagos-Laccadive Ridge (Fig. 1). The top 20-m late Pleistocene sec-

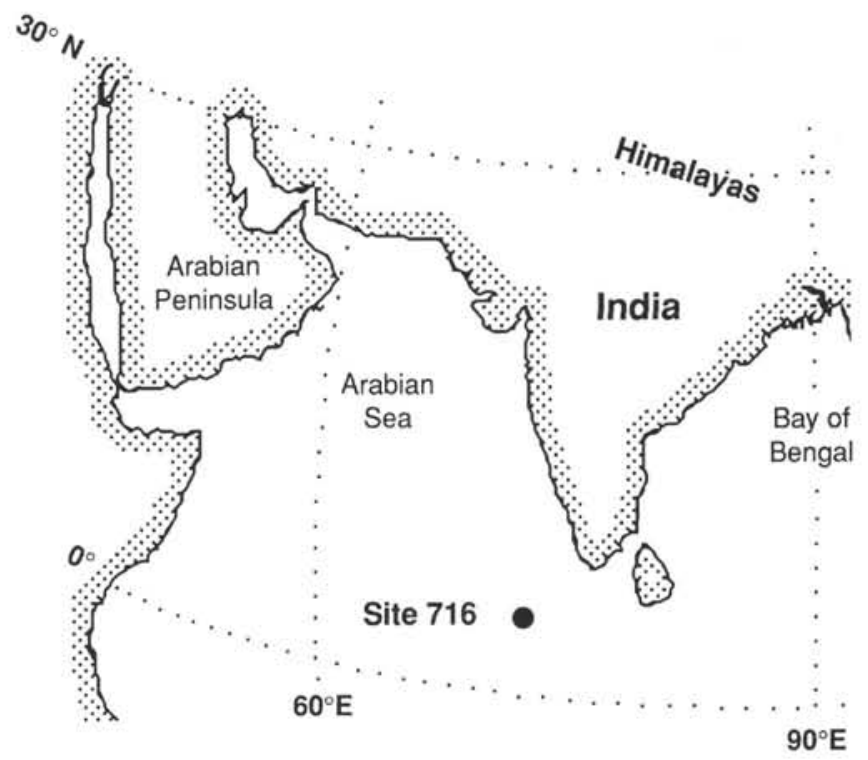

Figure 1. Map of the northern Indian Ocean showing the location of Site 716. 
tion exhibits sedimentation rates close to $3 \mathrm{~cm} / 1000 \mathrm{yr}$. Thus, Site 716 enables us to generate a high-resolution record of surface-water-induced faunal changes in the equatorial Indian Ocean. Because of the shallow water depth of Site $716(533 \mathrm{~m})$, faunal variations observed downcore should only contain information related to changes in the surface-water environment and little or no variation caused by changes in differential dissolution.

Specifically, the purpose of this report is to (1) establish a late Pleistocene time-stratigraphic framework for Hole 716B using variations in the stable oxygen isotope composition of foraminifer tests; (2) document downcore variations in the relative abundances of planktonic foraminifer species; (3) document variations in aragonite and calcite preservation using faunal information and faunal dissolution indexes; (4) investigate the extent to which the foraminifer faunal variation downcore in Hole 716B is related to changing surface-water conditions and/or influenced by differential dissolution; and (5) use downcore planktonic foraminifer faunas to reconstruct changes in SSTs at Site 716 over the past $600,000 \mathrm{yr}$ or so by means of the Modern Analog Technique (Prell, 1985).

\section{DEPOSITIONAL SETTING}

Site 716 is located within a shallow basin on the broad central plateau of the Maldive Ridge at a water depth of $533 \mathrm{~m}$. The topmost $250 \mathrm{~m}$ of the 1-1.5-km-thick sedimentary section was continuously cored with the advanced hydraulic piston corer (APC) in two holes (716A and 716B). A single lithologic unit was recovered that consisted of uniform, olive-shaded, foraminifer-bearing nannofossil calcareous ooze (Backman, Duncan, et al., 1988).

\section{SAMPLING}

The upper $50 \mathrm{~m}$ of sediment at Site 716 was extremely loose as a result of the high water content. This increased the likelihood of sediment disturbance during the core-splitting operation. More care in handling the Hole $716 \mathrm{~B}$ cores significantly reduced the problem encountered during the processing of Hole $716 \mathrm{~A}$. Thus, despite the fact that recovery in the upper three cores of Hole $716 \mathrm{~B}$ was $<100 \%$ and not as complete as in Hole $716 \mathrm{~A}$, we chose to sample Hole $716 \mathrm{~B}$ at $20-\mathrm{cm}$ intervals. We report here analyses from the $8010-\mathrm{cm}^{3}$ samples collected from all of Cores $115-716 \mathrm{~B}-1 \mathrm{H}$ and $-2 \mathrm{H}$, and Core 115-716B-3H down to Section 115-716B-3H-4, 40-42 cm. Leg 115 recovered $3.09 \mathrm{~m}$ of sediment within the $3.9-\mathrm{m}$ interval cored in Core $115-716 \mathrm{~B}-1 \mathrm{H}$ (78.2\% recovery), $9.47 \mathrm{~m}$ of sediment in Core $115-716 \mathrm{~B}-2 \mathrm{H}$, and $9.02 \mathrm{~m}$ in Core $115-716 \mathrm{~B}-3 \mathrm{H}$, within the $9.7 \mathrm{~m}$ cored in both cases ( $98.6 \%$ and $93.9 \%$ recovery, respectively). Therefore, we assume that at least $95 \mathrm{~cm}$ of sediment are missing between Cores $115-716 \mathrm{~B}-1 \mathrm{H}$ and $-2 \mathrm{H}$, and at least $13 \mathrm{~cm}$ are missing between Cores $115-716 \mathrm{~B}-2 \mathrm{H}$ and $-3 \mathrm{H}$.

\section{SAMPLE PROCESSING AND ANALYSIS}

Raw samples were processed according to Droxler et al. (this volume) with the following additions: a one-half split of the dried coarse fraction $(<63 \mu \mathrm{m})$ was sieved through a $150-\mu \mathrm{m}$ screen. The $>150-\mu \mathrm{m}$ size fraction was weighed, and aliquots of this material containing an average of 317 whole specimens of planktonic foraminifers were prepared. For each sample, we recorded (1) specimen counts of each planktonic foraminifer species; (2) total planktonic foraminifer fragments; (3) total Globorotalia menardii complex (G. menardii + Globorotalia tumida + Globorotalia menardii neoflexuosa); (4) total whole benthic foraminifer tests; (5) total whole pteropod tests; and (6) total pteropod fragments. Planktonic foraminifer species identifications are consistent with the taxonomy used in Cullen and Prell (1984), with the addition of one species category: Globo- rotalia anfracta Parker. All taxonomic categories are listed in Table 1.

\section{DATA}

Three sets of downcore data were generated for this study: stable isotope data, carbonate preservation data (dissolution data), and relative abundance data for planktonic foraminifer species.

\section{Stable Isotope Data}

The oxygen isotope composition of sized (300-355 $\mu \mathrm{m})$ samples of Globigerinoides sacculifer were analyzed at $20-\mathrm{cm}$ intervals to establish the oxygen isotope stratigraphy in the upper part of Hole $716 \mathrm{~B}$. The analytical procedure is discussed in Droxler et al. (this volume). All values are reported in per mil $(\% 0)$ difference relative to the PDB standard (Craig, 1957). Results are presented in Figure 2 and are discussed in detail below (see "Results" section, this chapter).

\section{Preservation Data}

We calculated the following indicators of relative carbonate dissolution from the $>150-\mu \mathrm{m}$ size fraction: (1) planktonic foraminifer fragmentation ( $\%$ whole foraminifers), (2) G. menardii complex fragmentation ( $\%$ whole $G$. menardii complex), (3) pteropod fragmentation ( $\%$ whole pteropods), and (4) pteropod whole-test abundance relative to planktonic foraminifer wholetest abundance. Each indicator is defined and statistically summarized in Table 2.

The first two indicators listed above can be used (1) to assess the calcite preservation state of a sample and (2) to assess the extent to which the differential dissolution of foraminifer species has modified the original faunal composition of the sample (Cullen, 1983; Cullen and Prell, 1984; Peterson and Prell, 1985a, 1985 b). Downcore variations in these indicators are presented in Figure 3. The last two indicators can be used to assess the aragonite preservation state of a sample. Downcore variations in these indicators are presented in Figure 4.

\section{Planktonic Foraminifer Faunal Data}

At least one specimen from each of 35 different taxonomic categories was recorded in the top $18.40 \mathrm{~m}$ of Hole 716B. Downcore faunas are dominated by 7 species that constitute $74 \%$ of the average species population. In total, 14 species have maximum abundances that exceed $4 \%$. The total faunal data is statistically summarized in Table 1 . Downcore variations of the 7 most abundant species are presented in Figure 5.

\section{RESULTS}

\section{Isotope Stratigraphy}

We compared the isotope record in Figure 2 with the composite $\delta^{18} \mathrm{O}$ record from Prell et al. (1986) and the stacked isotope record from Imbrie et al. (1984) and assigned isotope stages to the top $13 \mathrm{~m}$ of Hole 716B based upon this comparison. There is little or no ambiguity down to isotope stage 12 , which we identified as the $\delta^{18} \mathrm{O}$ maximum near $13 \mathrm{mbsf}$ (Fig. 2). Note that the early parts of isotope stage $5(5.3,5.4$, and 5.5$)$ between Cores $115-716 \mathrm{~B}-1 \mathrm{H}$ and $-2 \mathrm{H}$ are missing.

Below $13 \mathrm{mbsf}$, the isotope record is slightly more difficult to correlate with the composite record. The $\delta^{18} \mathrm{O}$ maximum near 16 mbsf was tentatively identified as isotope stage 16 . We are aware that this would then indicate a sharp decrease in sedimentation rate between isotope stages 12 and 16 . However, note that stage 12 is right at the break between Cores $115-716 \mathrm{~B}-2 \mathrm{H}$ and $3 \mathrm{H}$ (Fig. 2) and thus some of the section could be missing. In addition, isotope stage 14 is consistently an isotopically light glacial stage and thus is likely located between 13 and $16 \mathrm{mbsf}$ and is 
Table 1. Planktonic foraminifer taxonomic categories used in the present study along with their means and minimum and maximum occurrences in the upper $18.4 \mathrm{~m}$ of Hole 716B.

\begin{tabular}{|c|c|c|c|}
\hline $\begin{array}{l}\text { Planktonic } \\
\text { foraminifer species }\end{array}$ & $\begin{array}{c}\text { Mean }^{\mathrm{a}} \\
\text { (relative \%) }\end{array}$ & $\begin{array}{l}\text { Minimum } \\
\text { (relative \%) }\end{array}$ & $\begin{array}{l}\text { Maximum } \\
\text { (relative \%) }\end{array}$ \\
\hline Globigerinoides ruber (d'Orbigny) & 20.5 & 11.7 & 29.9 \\
\hline Globoquadrina dutertrei (d'Orbigny) & 12.1 & 5.5 & 18.8 \\
\hline Globigerinita glutinata (Egger) & 12.0 & 5.3 & 19.7 \\
\hline Globorotalia menardii (d'Orbigny) & 9.2 & 3.3 & 14.6 \\
\hline Globigerinoides sacculifer (Brady) & 7.8 & 3.1 & 18.8 \\
\hline Globigerina bulloides d'Orbigny) & 6.3 & 1.1 & 15.1 \\
\hline Pulleniatina obliquiloculata (Parker and Jones) & 5.8 & 1.8 & 11.7 \\
\hline Globigerinoides tenellus Parker & 4.4 & 1.5 & 7.3 \\
\hline Globigerina rubescens Hofker & 3.5 & 0.8 & 7.2 \\
\hline Globigerina falconensis Blow & 3.1 & 0.3 & 7.7 \\
\hline Globigerinella aequilateralis (Brady) & 2.7 & 0.4 & 6.0 \\
\hline Globigerina calida Parker & 2.3 & 0.4 & 4.4 \\
\hline Globoquadrina conglomerata (Schwager) & 2.1 & 0 & 4.6 \\
\hline Globoquadrina hexagona (Natland) & 0.9 & 0 & 3.2 \\
\hline Globorotalia crassiformis (Galloway and Wissler) & 0.9 & 0 & 3.9 \\
\hline Globorotalia tumida (Brady) & 0.7 & 0 & 2.3 \\
\hline Globigerinoides conglobatus (Brady) & 0.6 & 0 & 1.8 \\
\hline Orbulina universa d'Orbigny & 0.5 & 0 & 2.3 \\
\hline $\begin{array}{l}\text { Globorotalia truncatulinoides (d'Orgigny) right } \\
\text { coiling }\end{array}$ & 0.5 & 0 & 4.0 \\
\hline "pachyderma-dutertrei" intergrade & 0.5 & 0 & 2.1 \\
\hline Globorotalia theyeri Fleisher & 0.4 & 0 & 2.1 \\
\hline Globorotalia scitula (Brady) & 0.4 & 0 & 1.4 \\
\hline $\begin{array}{l}\text { Globigerina pachyderma (Ehrenberg) right } \\
\text { coiling }\end{array}$ & 0.2 & 0 & 1.7 \\
\hline Globorotalia anfracta Parker & 0.1 & 0 & 1.3 \\
\hline Candeina nitida d'Orbigny & 0.1 & 0 & 0.7 \\
\hline Sphaeroidinella dehiscens (Parker and Jones) & 0.1 & 0 & 0.7 \\
\hline Globigerinella adamsi (Banner and Blow) & 0 & 0 & 0.7 \\
\hline Globigerina digitata Brady & 0 & 0 & 0.4 \\
\hline Globigerina quinqueloba Natland & 0 & 0 & 0.7 \\
\hline $\begin{array}{l}\text { Globorotalia truncatulinoides (d'Orbigny, left } \\
\text { coiling }\end{array}$ & 0 & 0 & 0.8 \\
\hline Globorotalia inflata (d'Orbigny) & 0 & 0 & 0.6 \\
\hline Globigerina humilis (Brady) & 0 & 0 & 0.4 \\
\hline Globigerina pachyderma (Ehrenberg), left coiling & 0 & 0 & 0.4 \\
\hline Globorotalia menardii neoflexuosa & 0 & 0 & 0.3 \\
\hline Globorotalia hirsuta (d'Orbigny) & 0 & 0 & 0.3 \\
\hline
\end{tabular}

${ }^{\mathrm{a}}$ Number of samples $=80$.

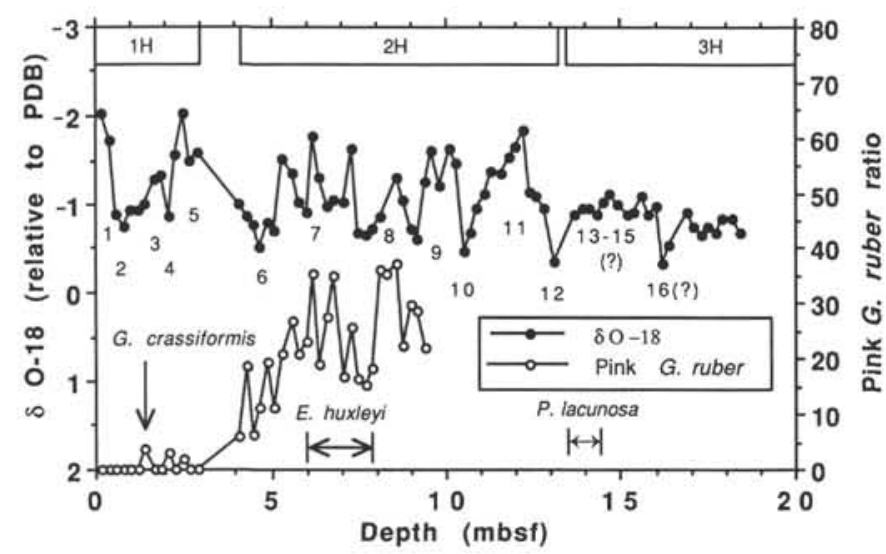

Figure 2. Stable oxygen isotope record for the upper $18.4 \mathrm{~m}$ of Hole $716 \mathrm{~B}$ with numbered isotope stages based upon analysis of Globigerinoides sacculifer. The abundance of the pink variety of $G$. ruber relative to the white variety is also shown, along with the downcore locations of three other important biostratigraphic datums identified (see text). Individual core lengths are shown at top. not the $\delta^{18} \mathrm{O}$ maximum at $16 \mathrm{mbsf}$ that has isotope values as heavy as other younger glacial stages. Any ambiguity should be resolved after we analyze samples from Hole 716A that overlap the boundary between Cores $115-716 \mathrm{~B}-2 \mathrm{H}$ and $-3 \mathrm{H}$, analyze Hole $716 \mathrm{~B}$ at $10-\mathrm{cm}$ intervals between 13 and $16 \mathrm{mbsf}$, and more precisely define the Pseudoemiliania lacunosa datum (see below).

The isotope stratigraphy in Figure 2 is consistent with the four biostratigraphic datums that are present in the equatorial Indian Ocean over the time-stratigraphic interval represented in the top $18 \mathrm{~m}$ of Hole 716B: (1) the last occurrence of P. lacunosa at 460,000 ka (Thierstein et al., 1977), which occurs in Hole 716B between 13.40 mbsf (Core 115-716B-2H-CC) and 14.25 mbsf; (2) the first occurrence of Emiliania huxleyi at $275,000 \mathrm{ka}$ (Thierstein et al., 1977), which occurs between 6.15 and 7.65 mbsf in Hole 716B; (3) the disappearance of the pink variety of Globorotalia ruber at 120,000 ka (Thompson et al., 1979), which occurs within the missing $95-\mathrm{cm}$ section between Cores $115-716 \mathrm{~B}-1 \mathrm{H}$ and $-2 \mathrm{H}$; and (4) the change in coiling direction in Globorotalia crassiformis (Oba, 1969), at around 41,000 ka (Hume and Prell, 1983), which occurs in Hole 716B at 1.40 mbsf.

These four datums are indicated on Figure 2. The isotope record indicates that the $E$. huxleyi datum should be just shallower than $7.65 \mathrm{~m}$ (within isotope stage 8; Thierstein, et al., 1977). The tentative position of the $P$. lacunosa datum indicates that some isotope stage 12 sediment is missing between Cores 
Table 2. Statistical summary of aragonite and calcite preservation indicators in the upper $\mathbf{1 8 . 4} \mathrm{m}$ of Hole $\mathbf{7 1 6 B}$.

\begin{tabular}{lcccc}
\hline Preservation indicator & Mean & Maximum & Minimum \\
\hline $\mathrm{a}_{\%}$ Whole foraminifers & 82.0 & 92.9 & 70.3 \\
$\mathrm{~b}_{\%}$ Whole G. menardii complex & 46.5 & 82.1 & 24.3 \\
$\mathrm{c}_{\%}$ Whole pteropods & 45.8 & 69.7 & 18.5 \\
$\mathrm{~d}_{\%}$ Pteropods & 20.0 & 36.4 & 1.5 \\
\hline
\end{tabular}

Note: Number of samples $=80$.

$$
\begin{aligned}
& \text { a } \% \text { Whole foraminifers }=\frac{\# \text { whole planktonic foraminifer tests, }>150 \mu \mathrm{m}}{(\# \text { whole planktonic foraminifer tests }>150 \mu \mathrm{m})+(\# \text { planktonic foraminifer fragments, }>150 \mu \mathrm{m})} \times 100 . \\
& { }^{\mathrm{b}} \% \text { Whole } G . \text { menardii complex }=\frac{\# \text { whole } G . \text { menardii tests, }>150 \mu \mathrm{m}}{(\# \text { whole } G . \text { Menardii complex tests }>150 \mu \mathrm{m})+(\# G . \text { menardii complex fragments }>150 \mu \mathrm{m})} \times 100 . \\
& \text { c } \% \text { Whole pteropods }=\frac{\# \text { whole pteropod tests, }>150 \mu \mathrm{m}}{(\# \text { whole pteropod tests }>150 \mu \mathrm{m})+(\# \text { pteropod fragments, }>150 \mu \mathrm{m})} \times 100 . \\
& \mathrm{d}_{\%} \text { Pteropods }=\frac{\# \text { whole pteropod tests, }>150 \mu \mathrm{m}}{(\# \text { whole pteropod tests }>150 \mu \mathrm{m})+(\# \text { planktonic foraminifer tests }>150 \mu \mathrm{m})} \times 100 .
\end{aligned}
$$

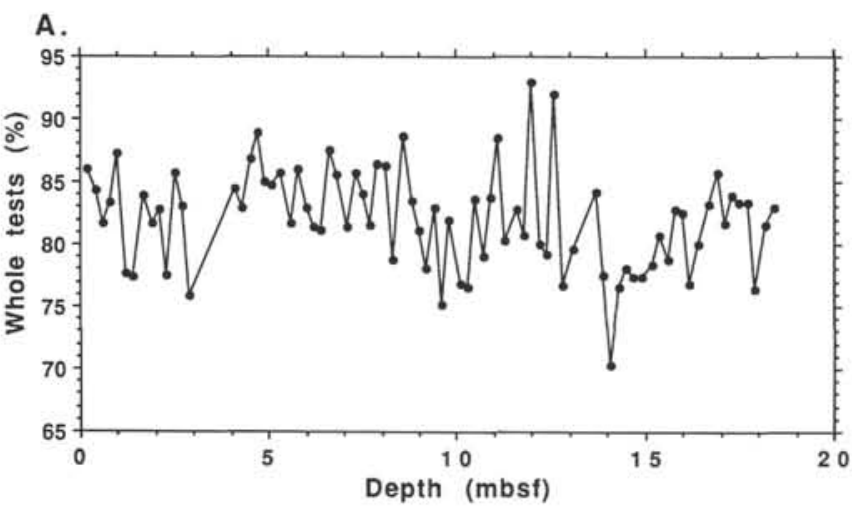

B.

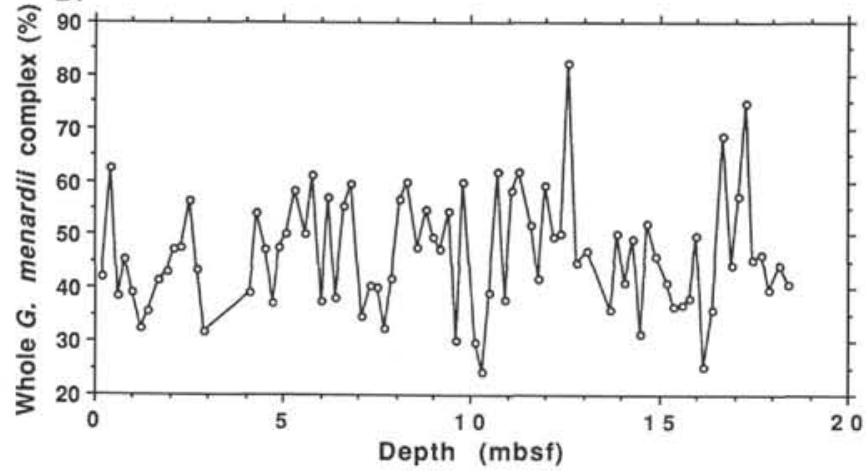

Figure 3. Downcore variations of calcite dissolution indicators in Hole 716B. A. $\%$ whole foraminifers. B. $\%$ whole Globorotalia menardii complex. Both variables increase with increased preservation of calcite. Indicators are defined in Table 2.

$115-716 \mathrm{~B}-2 \mathrm{H}$ and $-3 \mathrm{H}$, as previously suggested. In summary, the downcore isotope curve provides us with a consistent timestratigraphic framework for approximately the past $600,000 \mathrm{yr}$ and suggests that there are no problems associated with the downslope transport of coarse-fraction material from the shallower depths surrounding Site 716. Thus, we can evaluate downcore faunal and dissolution records within the context of glacial/interglacial climatic cycles over this time interval.
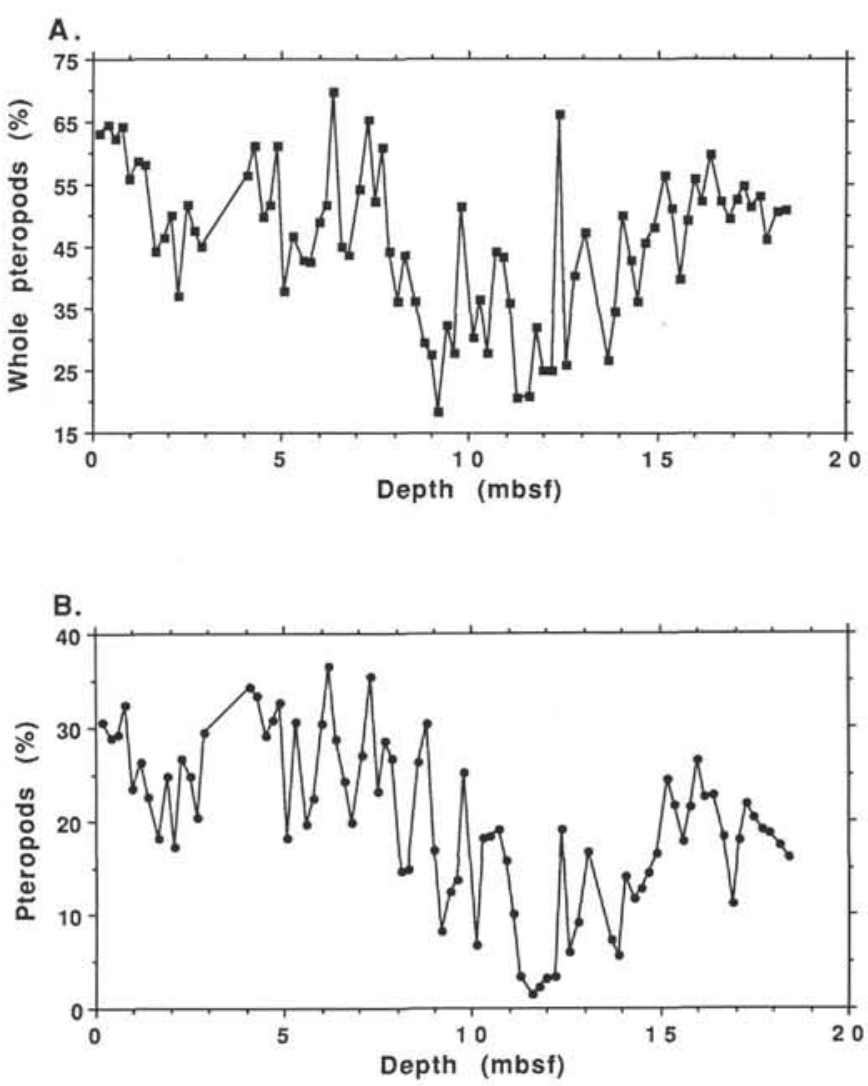

Figure 4. Downcore variations of aragonite dissolution indicators in Hole 716 B. A. $\%$ whole pteropods. B. $\%$ pteropods. Both variables increase with increased preservation of aragonite. Indicators are defined in Table 2.

\section{Preservation}

We have plotted the two calcite dissolution indicators calculated using the foraminifer species and fragment data. We chose to calculate $\%$ whole planktonic foraminifers (see Table 2) so that we could easily compare these data with those of Cullen (1983) and Peterson and Prell (1985a, 1985b). This indicator increases with increasing calcite preservation. Values in Hole 716B 

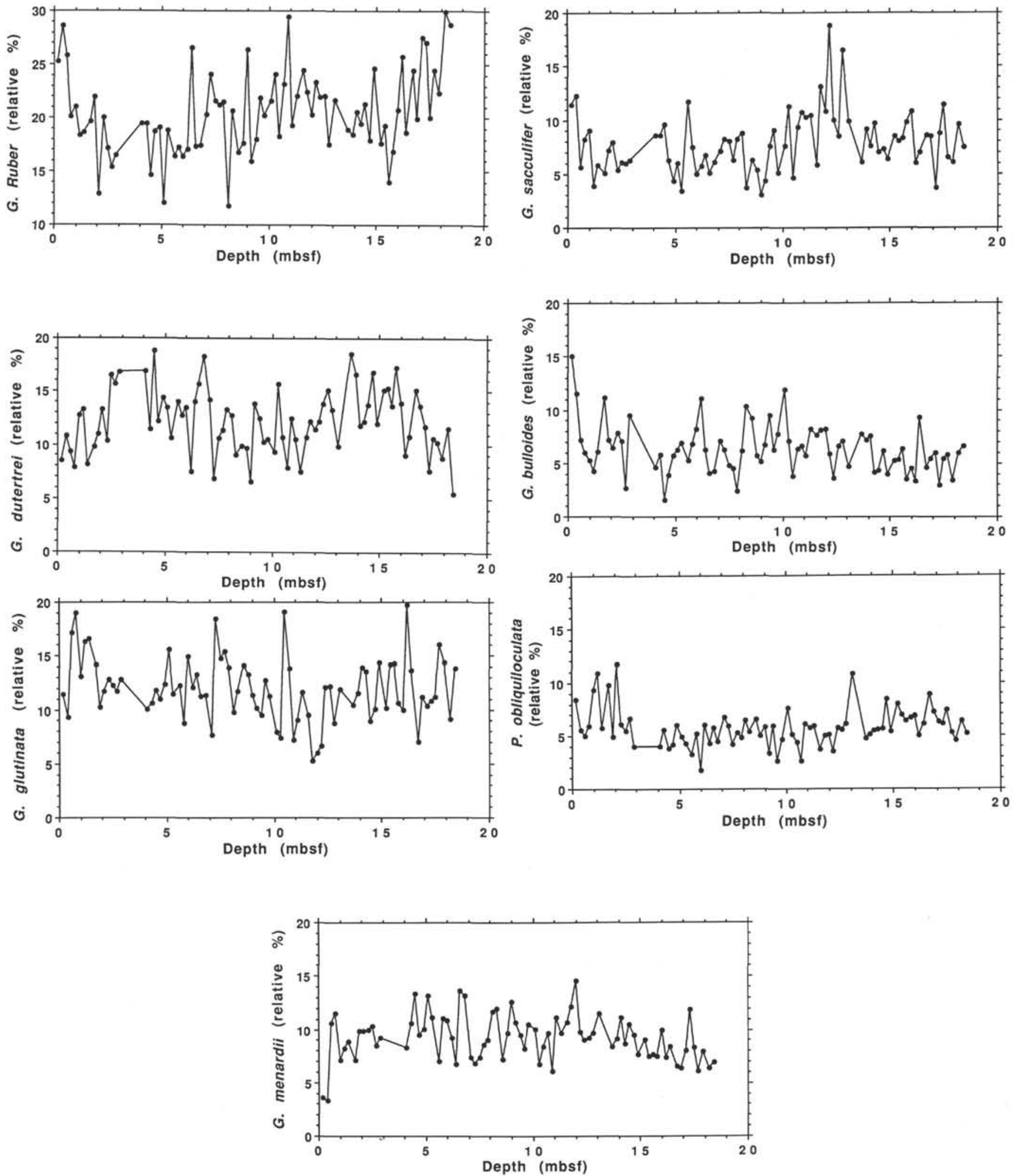

Figure 5. Downcore variations in the \% relative abundance of the seven most important species of planktonic foraminifers found in Hole 716B: Globigerinoides ruber, Globoquadrina dutertrei, Globigerinata glutinata, Globorotalia menardii, Globigerinoides sacculifer, Globigerina bulloides, and Pulleniatina obliquiloculata. 
average over $80 \%$ (Table 2) and, except for one value, never fall below $75 \%$. We compared our fragment data with northern Indian Ocean surface sediment data (Cullen, 1983; Peterson and Prell, 1985a). In these data sets, samples well above the foraminiferal lysocline consistently exhibit $\%$ whole foraminifer values of around $70 \%$. The higher values observed in Hole 716B samples would be expected in only the most well-preserved sediments in the northern Indian Ocean and indicates minimal dissolution of the $>150-\mu \mathrm{m}$ foraminifer material, consistent with the abundant aragonite present in Hole 716B sediments and its shallow depth.

Downcore variability in $\%$ whole foraminifers in Hole 716B was minimal. Much of the variation is likely to be related to random small-scale fluctuations that result from sample processing, for example. However, the presence of trends at frequencies lower than the small-scale fluctuations mentioned above cannot be completely ruled out (see below).

In addition to $\%$ whole foraminifers, we have calculated and plotted $\%$ whole $G$. menardii complex fragmentation as an indicator of calcite dissolution (Table 2 and Fig. 3B). Comparison of our data to northern Indian Ocean surface sediment data is consistent with results discussed above regarding $\%$ whole foraminifer data.

The lack of appreciable fragmentation suggests that variations in preservation have little or no influence on the variability that is observed in downcore foraminifer relative abundances. Thus, barring any appreciable downslope transport, we have a downcore record in which foraminifer changes can be unambiguously interpreted in terms of changes in above-site surface-water conditions.

To examine changes in aragonite preservation, we have plotted two pteropod dissolution indicators. We chose to calculate $\%$ whole pteropods and $\%$ pteropods (a ratio between whole pteropods and whole planktonic foraminifers), both of which should increase with increasing aragonite preservation (Fig. 4). Each indicator shows considerable high- and low-frequency downcore variability and indicates that the aragonite dissolution intensity undergoes systematic fluctuations at shallow water depths (note that high-frequency variability refers to frequencies producing periods on the order of $10^{4} \mathrm{yr}$ and low-frequency variability refers to frequencies producing periods on the order of $10^{5} \mathrm{yr}$ ).

A comparison of the two records reveals their expected high correlation. The two records do differ when the amplitude of change related to higher frequency variability is examined. We relied more heavily on the whole pteropod/whole foraminifer ratio here because pteropod fragment data cannot be as accurately collected as whole test data and because, as previously discussed, whole foraminifer tests relative to foraminifer fragments ( $\%$ whole foraminifers) changes little downcore and can be considered approximately constant. We have also assumed that the whole pteropod/whole foraminifer ratio has not been significantly affected by processes not associated with aragonite dissolution. Significant temporal changes in the ratio of pteropods to planktonic foraminifers in the surface waters above Hole $716 \mathrm{~B}$ could affect this variable, but not without reducing its correlation with $\%$ whole pteropods.

A decrease in both of the aragonite preservation indicators occurs within the $6-\mathrm{m}$ interval between 8 and 14 mbsf. In addition, a less intense decrease occurs between 1 and 3 mbsf. Superimposed upon the low-frequency trends are large-amplitude increases and decreases at much higher frequencies downcore. Thus, there is at least one long interval of increased aragonite dissolution that occurs in Hole 716B with many shorter intervals of change in aragonite preservation also apparent throughout the section.
An evaluation of aragonite preservation within the context of the stable isotope record for Hole $716 \mathrm{~B}$ indicates that aragonite preservation is poorest during isotope stage 11 and best during isotope stages $6,7.3$, and 7.5. Neither aragonite preservation curve exhibits a simple systematic relationship with the glacial/ interglacial cycles clearly defined by the isotope stratigraphy.

In summary, analysis of calcite preservation downcore indicates that sediments are consistently well-preserved. Thus, the downcore foraminifer faunal records discussed below are assumed to be completely free of any modification caused by differential dissolution. On the other hand, analyses of aragonite preservation downcore reveals that significant dissolution-related changes, at high and low frequencies, have occurred over the interval examined (see Droxler et al., this volume).

\section{Planktonic Foraminifer Faunas}

An examination of Table 1 and Figure 5 reveals that significant downcore variations in foraminifer species abundances have occurred over the past $600,000 \mathrm{yr}$. Most of the abundant species exhibit ranges near or well above $15 \%$ (Table 1). Downcore fluctuations of these magnitudes are important, particularly in the equatorial Indian Ocean, where non-dissolution-related downcore faunal changes are generally minor.

We closely examined the downcore variability of the seven most abundant species, along with any minor species that exhibited ranges above 4\% (Table 1). Important observations are briefly summarized as follows:

1. All abundant species show systematic high-frequency fluctuations of moderate to high amplitude throughout the section (Fig. 5).

2. For the two most abundant species, Globigerinoides ruber and Globorotalia dutertrei, there is a distinct low-frequency signal apparent. G. ruber appears to exhibit abundance minima between 2 and 7 mbsf and between 12 and 16 mbsf. On the other hand, $G$. dutertrei exhibits an abundance minima between 7 and 12 mbsf and at the top and bottom of the section. These long-term trends do not seem to be exhibited by any other species.

3. Two species, Globorotalia menardii and Globigerina bulloides, exhibit a distinct increase in their amplitude of variation within the depth interval from 11 to 13 mbsf. In addition, $G$. menardii exhibits a steady increase in abundance up to $12 \mathrm{mbsf}$. A third species, Pulleniatina obliquiloculata, seems to exhibit distinctly lower amplitude variability between 4 and 9 mbsf.

4. Globigerinoides sacculifer exhibits a distinct downcore abundance maximum centered around 12 mbsf.

5. Globigerinata glutinata exhibits rapid large-amplitude fluctuations, expressed as four distinct abundance maxima adjacent to distinct abundance minima.

6. Other less-abundant species exhibit smaller amplitude short-term fluctuations downcore with no detected uniqueness to their pattern of variation, with the exception of the right-coiling variety of $G$. truncatulinoides, which occurs in small abundances in the lower part of the section (below $14 \mathrm{mbsf}$ ) and abruptly disappears between 13 and 14 mbsf (Fig. 6).

7. Downcore interrelationships among abundant species are not simple, and little systematic covariation exists among species. Abundance maxima and minima for any two species do not consistently correspond along the entire section, nor is there any consistent offset between the maxima and minima of species. No two species patterns exhibit a correlation coefficient better than 0.45 , and only two species pairs (G. ruber-G. dutertrei and G. sacculifer-G. glutinata) exhibit correlation coefficients better than +0.4 . Decoupled species fluctuations downcore indicate that relative abundance patterns exhibit statistical 


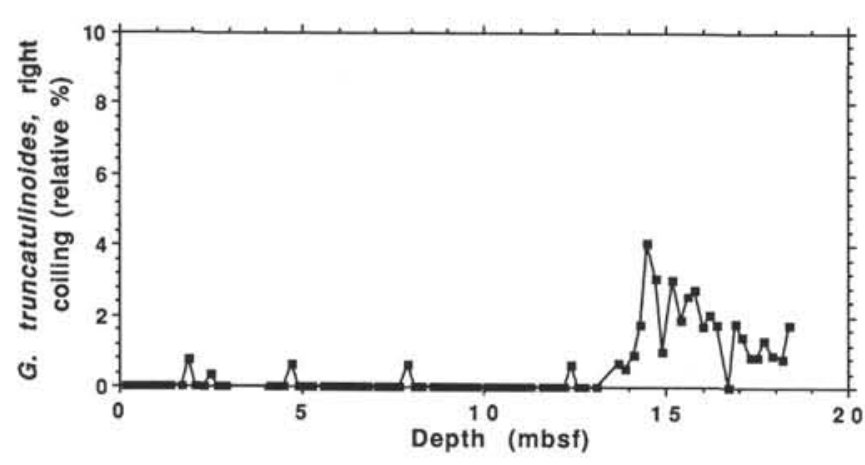

Figure 6. Downcore variation in \% relative abundance of right-coiling variety of Globorotalia truncatulinoides in Hole 716B.

independence. Faunas are of sufficient diversity so that matrix closure does not produce artificially high negative correlations between abundant species.

Downcore variations in the relative abundances of the seven most abundant species do not seem to have a simple relationship with glacial/interglacial cycles, as expressed by the stable isotope curve, particularly the two most abundant species, $G$. ruber and $G$. dutertrei. Nevertheless, the following observations are worth noting:

1. Globigerinita glutinata abundance is higher during glacial cycles, with abundance maxima centered around isotope stages 2,10 , and $16(?)$ as well as late stage 8 . This species is least abundant in isotope stage 11.

2. Pulleniatina obliquiloculata is most abundant during isotope stages 4 and 12 and during the isotope stage $3 / 2$ transition.

3. Globigerinoides sacculifer exhibits a peak of maximum abundance during the isotope stage $12 / 11$ transition and into the early part of stage 11. In general, abundance maxima of this species tend to occur during isotope stage transitions.

4. Globigerina bulloides is less abundant during glacial intervals.

In summary, foraminifer faunas exhibit noteworthy variability downcore in Hole 716B. Downcore patterns of the most important species are not highly correlated with each other, nor are they related in a simple manner to the glacial/interglacial cycles defined by the isotope stratigraphy.

We chose to analyze Hole $716 \mathrm{~B}$ faunal data further by comparing downcore faunas to modern faunas by means of the Modern Analog Technique (MAT). This technique was used in the study of Quaternary palynology (Prentice, 1980; Overpeck et al., 1985) and was first applied to planktonic foraminifer data by Hutson (1979) and more recently by Prell (1985).

The MAT directly compares the faunal composition of a downcore sample to a set of modern surface sediment samples; in this study, 1145 core-top samples from a worldwide data base. We used the squared chord distance to calculate the dissimilarity between each sample in Hole 716B and all core-top samples. Dissimilarity values can range from 0 (identical) to 2.0 (most dissimilar). We then identified the 10 most similar modern samples for each downcore sample and calculated the mean of the dissimilarity coefficients for these 10 modern analogs. For no downcore sample was this mean value $>0.174$, suggesting the presence of a good set of modern analogs for all Hole 716B samples. However, some samples have a better 10-sample subset of analogs than others, as indicated by the downcore variation in the mean dissimilarity coefficient (Fig. 7).

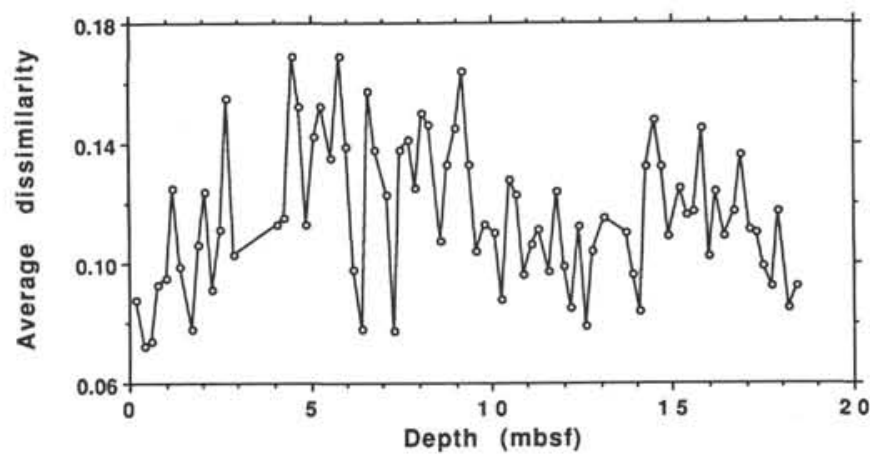

Figure 7. Downcore variations in the means of the dissimilarity coefficients of the 10 modern surface sediment analogs most similar to each sample in Hole 716B (see text).

In all, only 12 modern samples outside of the northern Indian Ocean appeared in the analog subset of any downcore sample, and only one, a shallow sample from the margin of northwest Australia, was a particularly important analog for a number of Hole 716B samples. In general, interglacial samples seem to have a slightly more similar set of modern analogs than glacial samples. However, the low mean dissimilarity coefficients for all samples indicate that surface-water conditions above Site 716 were within the range of modern-day, surface-water conditions in the tropical Indian Ocean. Thus, the shallow location of Site 716 within the Maldives Archipelago did not seem to produce any surface-water conditions anomalous enough to create dissimilar foraminifer faunas caused, for example, by restricted surface circulation in the region. In addition, we feel that mean dissimilarity coefficients would have been even lower if the modern data set included a larger number of shallow wellpreserved samples from the equatorial ocean or if we chose to compare Hole 716B samples to only the top five modern analogs.

\section{SST Variations at Site 716}

Downcore changes in planktonic foraminifer species abundances are in response to changes in the environmental conditions of surface waters over the 600,000 -yr time interval represented by the upper $18.4 \mathrm{~m}$ of Hole $716 \mathrm{~B}$. For our initial analysis, we assume that SST is an important component of the environment and is systematically related to other ecologically important properties of overlying surface waters (salinity and nutrient levels, for example). Therefore, we used the SST data of the 10 best modern analogs for each downcore sample to estimate SST changes at Site 716 by calculating the mean warm and cold monthly SST from the average February and August SSTs above each of the 10 modern analogs. Warm SST estimates were calculated by averaging the highest of the February and August SSTs for each analog location; cold SSTs were estimated by averaging the lowest of the February and August SSTs for each analog location. The results were plotted in Fig. 8. Calculating warm and cold SST estimates (instead of August and February SSTs) avoids the problem of averaging Southern Hemisphere summer SSTs (February) and Northern Hemisphere winter SSTs (February) when modern analogs come from both hemispheres.

This approach, however, makes it difficult to decide which set of estimates, warm or cold, should be used if one desires to evaluate calendar season SST changes, particularly in the tropics. For example, February and August SSTs above Hole 716B are $28.1^{\circ}$ and $28.0^{\circ} \mathrm{C}$, respectively. So, presently, February (i.e., Northern Hemisphere winter) SSTs are slightly warmer than August (i.e., Northern Hemisphere summer) SSTs in this part 
A.

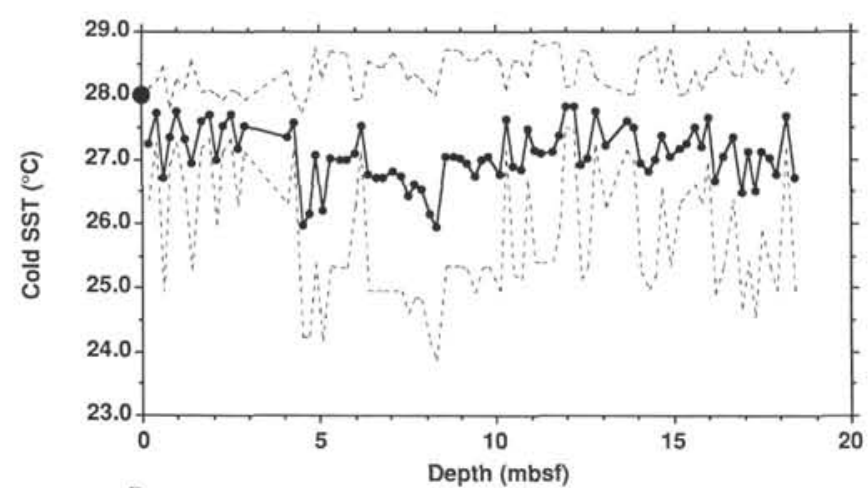

B.

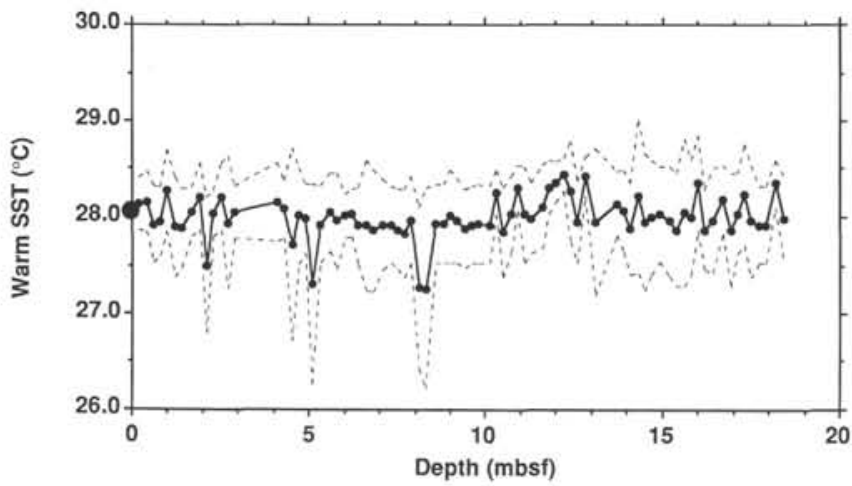

Figure 8. Downcore sea-surface temperature (SST) estimates calculated by averaging observed SSTs above the 10 most similar modern analogs for each Hole 716B sample. A. Cold SST. B. Warm SST. Dotted lines connect the average SST \pm the standard deviation of the SSTs above the 10 best modern analogs for each downcore sample (standard deviation "envelope"; see text). Modern observed warm and cold SSTs above Site 716 are shown as large dots on temperature axis.

of the equatorial Indian Ocean. This presents a problem as to which set of downcore SST estimates corresponds to which calendar season. Mix et al. (1986) attempted to avoid this problem by examining mean annual SST estimates and annual temperature ranges in a series of downcore samples from the tropical Atlantic Ocean. Here we present SST estimates as warm and cold without assigning a seasonal significance to either set of estimates. Close analysis of a more up-to-date set of SST maps and a better understanding of the seasonal evolution of SST in the equatorial Indian Ocean should enable us to assign seasonal significance to the warm and cold SST estimates in the future.

The precision of SST estimates using the MAT approach can be assessed using the core-top data set. Prell (1985) applied the technique to each core top in the Indian Ocean and compared the resulting SST estimate based on the ten closest analogs with the observed SST above each site. Linear regression of warm and cold analog SST estimates with observed warm and cold SSTs yielded correlation coefficients of 0.99 in both cases, and standard errors of $<1.0^{\circ}\left(0.89^{\circ}\right.$ and $0.95^{\circ} \mathrm{C}$, respectively; Prell, 1985). The MAT approach does a better estimating job than the approach using factor analysis and regression ("CLIMAP equations”; Hutson and Prell, 1980; Prell, 1985).

The precision of individual downcore SST estimates can be evaluated by calculating the standard deviation of the above-site SSTs of the ten most similar modern analogs used to estimate the SSTs for each downcore sample. The average standard deviation for the warm and cold SST estimates is $0.46^{\circ}$ and $1.30^{\circ} \mathrm{C}$, respectively. For warm SSTs, there is a tendency for the stan- dard deviations of individual estimates to increase with increasing average dissimilarities. The pattern is not as clear for cold SSTs. Standard deviation "envelopes" are plotted with the downcore SST estimates in Figure 8.

Warm SST estimates exhibit little downcore variability, averaging $28.00^{\circ} \mathrm{C}$, with a standard deviation of $0.22^{\circ} \mathrm{C}$ and a range of $1.18^{\circ} \mathrm{C}$. Despite the overall lack of downcore warm SST changes, two points regarding SST maxima and minima are apparent: (1) three distinct SST minima (corresponding to $-0.5^{\circ} \mathrm{C}$ deviations from estimates in adjacent samples) were observed in the warm SST pattern, and warm SSTs fall below $27.5^{\circ} \mathrm{C}$ during glacial isotope stages 4,6 , and 8 ; and (2) SST estimates are slightly higher (approaching $28.5^{\circ} \mathrm{C}$ ) during the isotope stage $12 / 11$ transition and into the early part of stage 11 .

Cold SST estimates exhibit higher amplitude downcore variability, averaging $27.07^{\circ} \mathrm{C}$ with a standard deviation of $0.44^{\circ} \mathrm{C}$ and an overall SST range of nearly $2^{\circ} \mathrm{C}\left(1.88^{\circ} \mathrm{C}\right)$. Systematic high-frequency SST changes of $1^{\circ} \mathrm{C}$ were observed throughout much of the core, superimposed upon a lower frequency trend of lower SSTs within the 4-9-mbsf interval and higher SSTs between 10 and $15 \mathrm{mbsf}$ and above 3 mbsf. Downcore SST estimates imply that cold SSTs in this area have never been as high as observed today and have been as much as $2^{\circ} \mathrm{C}$ lower (i.e., $<26^{\circ} \mathrm{C}$ ) during glacial isotope stages 6 and 8 . Cold SST estimates are compared with Hole $716 \mathrm{~B}$ stable isotope stratigraphy in Figure 9. A direct comparison of the warm and cold SST patterns indicates that seasonal SST changes were much more pronounced over the past $600,000 \mathrm{yr}$ than observed today, particularly in glacial isotope stage 6 (Fig. 10).

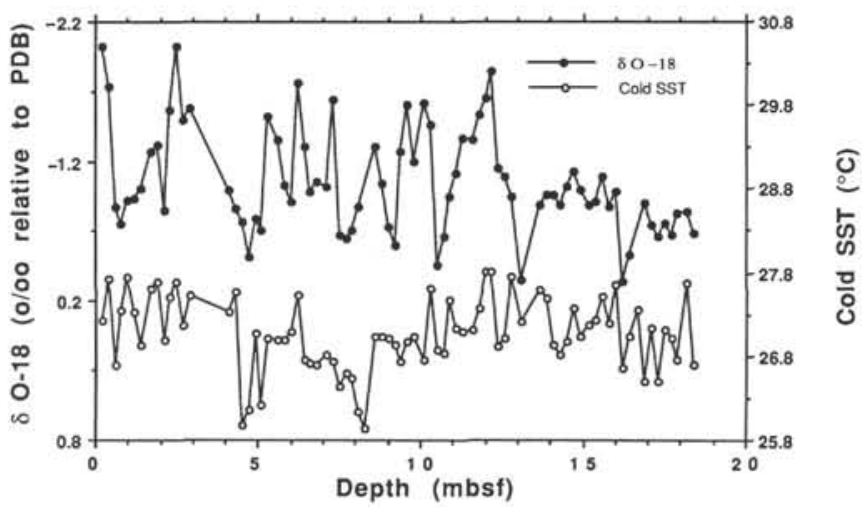

Figure 9. Cold SST estimates plotted alongside oxygen isotope stratigraphy of Hole 716B.

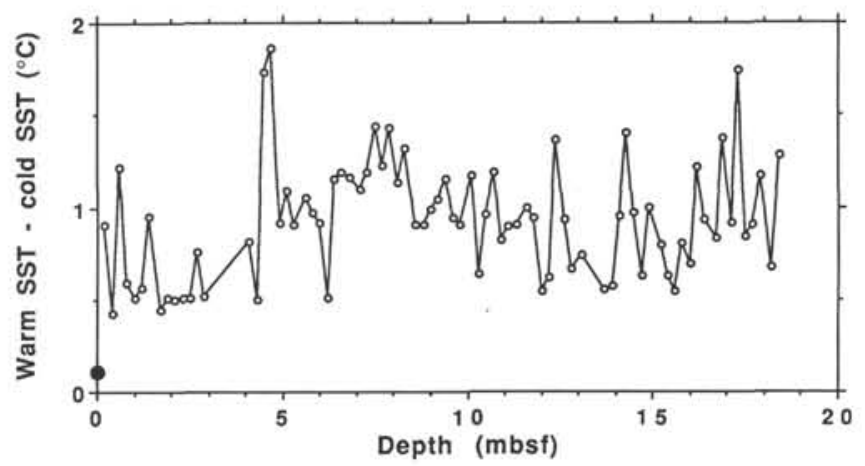

Figure 10. Downcore variations in seasonality calculated as the difference between warm and cold SST estimates (warm SST - cold SST). Modern SST seasonality is shown as a solid dot at 0 depth. 
A comparison of downcore SST patterns with downcore relative abundance variations of important species reveals no particularly strong linear correspondence between patterns. None of the seven most abundant species patterns are highly correlated to SST patterns. Four species ( $G$. ruber, $G$. sacculifer, $G$. dutertrei, and $G$. bulloides) exhibit low positive linear correlation with downcore SST (Table 3), whereas three species ( $G$. glutinata, $G$. menardii, and $P$. obliquiloculata) exhibit low negative linear correlation with downcore SST (Table 3). A less abundant species, Globigerina falconensis, exhibits the highest correlation with downcore SSTs $(-0.56$ and -0.52 for warm and cold SST, respectively). These observations suggest that downcore faunal changes may be in response to ecologically important environmental factors other than SST. Sea-surface salinity has been shown to be an environmental factor important in controlling the surface sediment distribution of foraminifer species in the northern Indian Ocean (Cullen, 1981, 1984). In addition, Cullen $(1984,1985)$ has demonstrated the importance of nutrient levels and chlorophyll- $a$ concentrations in surface waters as other environmental factors that partially control the relative abundances of foraminifer species in well-preserved surface sediments in the northern Indian Ocean.

\section{DISCUSSION}

The results we have presented above have some important implications regarding surface- and intermediate-water conditions in the equatorial Indian Ocean. Variations in pteropod preservation over the past $600,000 \mathrm{yr}$ suggest systematic highand low-frequency variations in the carbonate chemistry at 300$500 \mathrm{~m}$ depth in the equatorial Indian Ocean. The long interval of poorest pteropod preservation centered on interglacial isotope stage 11 seems to correlate with an interval of very poor foraminifer preservation observed in deeper water cores from the Ninetyeast Ridge (Peterson and Prell, 1985b). Thus, an interval of increased aragonite dissolution at shallow depths, as observed in Hole 716B, occurs during an interval of increased calcite dissolution at depth, as observed in deep-water cores to the east of Hole 716B (see Droxler et al., this volume). Whether the considerable high-frequency variation in aragonite preservation suggested by pteropod variations (Fig. 4) is related to high-frequency variations in calcite preservation in deeper waters awaits further investigation (see Droxler et al., this volume).

Our results show that very little dissolution of foraminifer tests occurs in the $>150-\mu \mathrm{m}$ size fraction. Thus, downcore faunal records are not influenced by the process of differential dissolution that often is responsible for much of the downcore species variation observed in equatorial cores from greater depths. Despite constant excellent foraminifer preservation downcore, Hole 716B exhibits significant faunal variability, which should

Table 3. Linear correlation coefficients of the ten most abundant foraminifer species with warm and cold SST estimates in the upper 18.4 $\mathrm{m}$ of Hole 716B.

\begin{tabular}{lcc}
\hline & Warm SST & Cold SST \\
\hline Globigerinoides ruber & $0.43(0)$ & $0.13(0.12)$ \\
Globoquadrina dutertrei & $0.05(0.31)$ & $0.14(0.12)$ \\
Globigerinita glutinata & $-0.39(0)$ & $-0.31(0)$ \\
Globorotalia menardii & $-0.24(0.02)$ & $-0.24(0.02)$ \\
Globigerinoides sacculifer & $0.49(0)$ & $0.34(0)$ \\
Globigerina bulloides & $0.03(0.38)$ & $0.29(0.01)$ \\
Pulleniatina obliquiloculata & $-0.06(0.29)$ & $0.21(0.03)$ \\
Globigerinoides tenellus & $0.05(0.33)$ & $-0.16(0.08)$ \\
Globigerina rubescens & $-0.30(0)$ & $-0.39(0)$ \\
Globigerina falconensis & $-0.56(0)$ & $-0.52(0)$ \\
\hline
\end{tabular}

Note: Numbers in parentheses are the significance levels for each Person moment correlation coefficient. be in ecological response to changing environmental conditions in the surface waters. Faunal changes downcore suggest that the surface-water environment in the equatorial Indian Ocean has undergone systematic high- and low-frequency changes over the past 600,000 yr. Any relationship between surface-water changes in the equatorial Indian Ocean and global glacial/interglacial cycles cannot be determined by simple comparison of various downcore records.

A comparison of species variations with variations in pteropod preservation indicates that there is no significant correspondence between patterns of variability. However, Globigerinoides sacculifer does exhibit its previously discussed conspicuous abundance maximum during the interval of poorest aragonite preservation. Globigerinoides sacculifer is one of the only two species that exhibit some degree of linear correlation with variations in pteropod preservation $(r=-0.32)$; the other is Globigerinoides glutinata $(r=+0.42)$. However, the overall lack of correlation between species variations and pteropod preservation indicates that there is no simple interrelationship between changes in equatorial surface waters and geochemical changes in the waters below.

The downcore SST estimates calculated using the MAT approach indicate that SSTs, particularly warm SSTs, have changed little over the last $600,000 \mathrm{yr}$. However, despite that fact that high-frequency SST variability exhibits amplitudes that are, for the most part below $1{ }^{\circ} \mathrm{C}$, the cold SST estimates produce what we interpret as a systematic downcore pattern. Most of the variation is of a magnitude similar to the precision of most individual estimates for downcore samples as expressed by the standard deviation of the observed SSTs of their ten modern analogs. This fact, along with the previously discussed high-amplitude downcore variations observed in species relative abundances, strongly suggest that faunal changes are in response to other ecologically important environmental variables (i.e., salinity and/ or nutrient levels). Using the MAT approach and the biogeographic modeling techniques presented in Cullen (1984, 1985), we plan to further investigate the role of salinity and/or nutrient levels in producing faunal variation in Hole 716B.

\section{SUMMARY AND CONCLUSIONS}

Hole $716 \mathrm{~B}$ contains a nearly continuous sequence of biogenic sediments for the past $600,000 \mathrm{yr}$. Small amounts of sediment are missing between the two core breaks present in the top $18.4 \mathrm{~m}$ of Hole $716 \mathrm{~B}$. The downcore oxygen isotope record of Hole 716B can be confidently correlated with the global composite isotopic record down to isotope stage $12(\sim 423,000 \mathrm{ka})$ and preliminarily down to isotope stage $17(\sim 670,000 \mathrm{ka})$. Four biostratigraphic datums are consistent with the established isotope stratigraphy.

Because of its shallow depth $(533 \mathrm{~m})$, little or no differential dissolution of foraminifer species was observed. Downcore calcite preservation indicators indicate little variability and imply that there is excellent preservation throughout the interval examined. Significant systematic variation in pteropod preservation was observed. A long interval of poor aragonite preservation occurs within isotope stages 9-13, with significant higher frequency variations in aragonite preservation superimposed upon the lower frequency trend. The long interval of aragonite dissolution at intermediate depths occurs during a time when more intense calcite dissolution is occurring in the deeper waters of the equatorial Indian Ocean.

Significant systematic downcore variability was observed in the relative abundances of the important species of planktonic foraminifers. Downcore faunal variation is in direct response to changes in the environmental conditions of surface waters. Downcore species abundance patterns for the seven dominant species lack any significant correlation, implying that these spe- 
cies are responding independently to environmental changes in the surface waters.

The Modern Analog Technique can be used to compare Hole 716B faunas directly with modern surface sediment faunas. Similar modern analogs were found for all downcore samples. The overwhelming majority of modern analogs are well-preserved samples from the northern Indian Ocean. Warm and cold SST estimates were calculated for Hole $716 \mathrm{~B}$ with the MAT. Warm SSTs have changed little over the past $600,000 \mathrm{yr}$ and are similar to modern conditions. Cold SST estimates are consistently cooler than modern SSTs, particularly during glacial isotope stage 6 and 8 , in which estimates are below $26^{\circ} \mathrm{C}$. At no time during the past $600,000 \mathrm{yr}$ was seasonality as low in the central equatorial Indian Ocean as observed today.

Downcore species variability is too significant to be in direct response to equatorial SST changes. Foraminifer species are more likely responding to changes in other environmentally important aspects of the equatorial surface waters that may be partially (or totally) independent of changes in SST, such as salinity and nutrient levels. Preliminary results indicate that surface-water environmental conditions and intermediate-depth $(500 \mathrm{~m})$ geochemistry respond independently of each other and are not related in a simple manner to global glacial/interglacial cycles, as revealed by the oxygen isotope record.

\section{ACKNOWLEDGMENTS}

This research was supported by USSAC-JOI grants to J. L. Cullen and A. W. Droxler and partially by NSF grant OCE8796273 to A. W. Droxler. We thank the personnel of the ODP Core Depository in College Station, Texas, particularly Chris Mato, for help during core sampling. In addition, we thank A. Martin for her species identification work and M. Bocko, D. Gellar, R. Lucci, and L. Pizzano for their capable technical assistance during sample processing and analysis. We are grateful to R. E. Dunbar, who made his Stable Isotope Laboratory at Rice University available for oxygen isotope analyses, and to M. J. Anderson and K. Coombe for typing the manuscript. Finally, we gratefully acknowledge the excellent suggestions of the two reviewers of the manuscript.

\section{REFERENCES}

Backman, J., Duncan, R. A., et al., 1988. Proc. ODP, Init. Repts., 115: College Station, TX (Ocean Drilling Program).

Craig, H., 1957. Isotopic standards for carbon and oxygen correction factors for mass spectrometric analysis of $\mathrm{CO}_{2}$. Geochim. Cosmochim. Acta, 12:133-149.

Cullen, J. L., 1981,. Microfossil evidence for changing salinity patterns in the Bay of Bengal over the past 20,000 yr. Palaeogeogr., Palaeoclimatol., Palaeoecol., 35:315-356.

1984. Climatic variation in the northern Indian Ocean: analysis of the distribution, ecology, and preservation of planktonic foraminifera in late Quaternary sediments (Ph.D. thesis). Brown Univ., Providence, RI
1985. Models of planktonic foraminiferal biogeography in northern Indian Ocean surface sediments: the role of environment and preservation. Geol. Soc. Am., Abstr. Programs, 17:557.

Cullen, J. L., and Prell, W. L., 1984. Planktonic foraminifers in northern Indian Ocean surface sediments: distribution and preservation. Mar. Micropaleontol., 9:1-52.

Hume, A. E., and Prell, W. L., 1983. A time-transgressive biohorizon in the tropical Indian Ocean: the change in coiling direction of $G$. crassiformis. Geol. Soc. Am. Abstr. Programs, 12:452.

Hutson, W. H., 1979. The Agulhas Current during the late Pleistocene: analysis of modern faunal analogs. Science, 207:64-66.

Hutson, W. H., and Prell, W. L., 1980. A paleoecological transfer function, Fl-2, for Indian Ocean planktonic foraminifera. J. Paleontol., 54:381-399.

Imbrie, J., Hays, J. D., Martinson, D. G., McIntyre, A., Mix, A. C., Morley, J. J., Pisias, N. G., Prell, W. L., and Shackleton, N. J., 1984. The orbital theory of Pleistocene climate: support from a revised chronology of the marine $\delta^{18} \mathrm{O}$ record. In Berger, A., Imbrie, J., Hays, J., Kukla, G., and Saltzman, B. (Eds.), Milankovitch and Climate: Hingham, MA (D. Riedel), 260-305.

Mix, A. C., Ruddiman, W. F., and McIntyre, A., 1986. The late Quaternary paleoceanography of the tropical Atlantic. 1: Spatial variability of annual mean sea-surface temperatures, $0-20,000$ years B.P. Paleoceanography, 1:43-66.

Oba, T., 1969. Biostratigraphy and isotopic paleotemperatures of some deep-sea cores from the Indian Ocean. Sci. Rep. Tohoku Univ., Ser. 2, 41:129-195.

Overpeck, J. T., Webb, T., III, and Prentice, I. C., 1985. Quantitative interpretation of fossil pollen spectra: dissimilarity coefficients and the method of modern analogs. Quat. Res., 23:87-108.

Peterson, L. C., and Prell, W. L., 1985a. Carbonate dissolution in Recent sediments of the eastern equatorial Indian Ocean: preservation and carbonate loss above the lysocline. Mar. Geol., 64:259-290.

1985b. Carbonate preservation and rates of climatic change: an 800 kyr record from the Indian Ocean. In Sundquist, E. T., and Broecker, W. S. (Eds.), The Carbon Cycle and Atmospheric $\mathrm{CO}_{2}$ : Natural Variations Archean to Present: Washington (American Geophysical Union), 32:251-269.

Prell, W. L., 1985. The stability of low-latitude sea-surface temperatures: an evaluation of the CLIMAP reconstruction with emphasis on the positive SST anomalies. Dept. Energy Tech. Rept., TR-025.

Prell, W. L., Imbrie, J., Martinson, D. G., Morley, J. J., Pisias, N. G., Shackleton, N. J., and Streeter, H. F., 1986. Graphic correlation of oxygen isotope stratigraphy: application to the late Quaternary. $\mathrm{Pa}$ leoceanography, 2:137-162.

Prentice, I. C., 1980. Multidimensional scaling as a research tool in Quaternary palynology: a review of theory and methods. Rev. Palaeobot. Palynol., 31:71-104.

Thierstein, H. R., Geitzenauer, K. R., Molfino, B., and Shackleton, N. J., 1977. Global synchroneity of late Quaternary coccolith datum levels: validation by oxygen isotopes. Geology, 5:400-404.

Thompson, D. R., Bé, A.W.H., Duplessy, J. C., and Shackleton, N. J., 1979. Disappearance of pink-pigmented Globigerinoides ruber at 120,000 yr B.P. in the Indian and Pacific Oceans. Nature, 280:554558.

Date of initial receipt: 17 August 1989

Date of acceptance: 19 January 1990

Ms 115B-172 